\title{
Protein Changes in Response to Heat Stress in Acclimated and Nonacclimated Creeping Bentgrass
}

\author{
Yali He', Xiaozhong Liu, and Bingru Huang² \\ Department of Plant Biology and Pathology, Rutgers University, New Brunswick, NJ 08901
}

AdDitional INDEX wORDs. Agrostis palustris, heat tolerance, heat shock proteins, protein contents

\begin{abstract}
The acclimation of plants to moderately high temperature plays an important role in inducing plant tolerance to subsequent lethal high temperatures. This study was performed to investigate the effects of heat acclimation and sudden heat stress on protein synthesis and degradation in creeping bentgrass (Agrostis palustris Huds.). Plants of the cultivar Penncross were subjected to two temperature regimes in growth chambers: 1) heat acclimation - plants were exposed to a gradual increase in temperatures from 20 to 25,30 , and $35^{\circ} \mathrm{C}$ for 7 days at each temperature level before being exposed to $40{ }^{\circ} \mathrm{C}$ for 28 days; and 2) sudden heat stress (nonacclimation) - plants were directly exposed to $40{ }^{\circ} \mathrm{C}$ for 28 days from $20^{\circ} \mathrm{C}$ without acclimation through the gradual increase in temperatures. Heat acclimation increased plant tolerance to subsequent heat stress, as demonstrated by lower electrolyte leakage (relative EL) in leaves of heat-acclimated plants compared to nonacclimated plants at $40{ }^{\circ} \mathrm{C}$. Heat acclimation induced expression of some heat shock proteins (HSPs), 57 and $54 \mathrm{kDa}$, detected in a salt-soluble form (cystoplasmic proteins), which were not present in unacclimated plants under heat stress. However, HSPs of 23,36 , and $66 \mathrm{kDa}$ were induced by both sudden and gradual exposure to heat stress. In general, total protein content decreased under both heat acclimation and sudden heat stress. Cystoplasmic proteins was more sensitive to increasing temperatures, with a significant decline initiated at $25^{\circ} \mathrm{C}$, while sodium dodecyl sulphate (SDS)-soluble (membrane) protein content did not decrease significantly until temperature was elevated to $30^{\circ} \mathrm{C}$. The results demonstrated that both a gradual increase in temperature and sudden heat stress caused protein degradation and also induced expression of newly synthesized HSPs. Our results suggested that the induction of new HSPs during heat acclimation might be associated with the enhanced thermotolerance of creeping bentgrass, although direct correlation of these two factors is yet to be determined. This study also indicated that protein degradation could be associated with heat injury during either gradual increases in temperature or sudden heat stress.
\end{abstract}

High temperature stress is a major environmental factor limiting plant growth in tropical and subtropical areas (Radin et al., 1994). High temperature inhibits photosynthesis, limits carbohydrate accumulation, damages cell membranes and leads to cell death (Liu and Huang, 2000). Plants have the ability to acquire thermotolerance by exposure to a gradual increase in temperature (heat acclimation) (Hong et al., 2003; Vierling, 1991), which often occurs in the natural environment. Understanding mechanisms of heat acclimation will facilitate the development of new strategies for crop improvement under high temperature stress.

Cellular membranes are among the most sensitive components of a plant cell to heat stress (Raison et al., 1980). Heat stress may disrupt membranes and leads to the leakage of organic and inorganic solutes (electrolytes) from the cell (Levitt 1980). Electrolyte leakage of cells is widely used to evaluate membrane thermostability (Marcum et al., 1998). The ability of maintaining high membrane thermostability under heat stress is positively correlated to whole-plant tolerance to heat stress (Howarth et al., 1997; Marcum et al., 1998).

Plants produce a family of proteins called heat shock proteins (HSPs) in response to either rapid heat shock or a gradual increase in temperature (Al-Niemi and Stout, 2002; Nguyen et al., 1994; Vierling, 1991). Based on their molecular weight, the major HSPs synthesized by plants belong to five classes: HSP100, HSP90, HSP70, HSP60 (kDa), and small HSPs $(\approx 17$ to $30 \mathrm{kDa}$ ) (Vierling, 1991). Proteins in plant cells are also classified into different groups based on their solubility properties

Received for publication 15 Nov. 2004. Accepted for publication 9 Feb. 2005. ${ }^{1}$ College of Agriculture and Biology, Shanghai Jiaotong Univ., Shanghai 201101, P.R.China

2To whom reprint requests should be addressed. E-mail address: huang@aesop. rutgers.edu and localization in cells (Loponen et al., 2004). Salt- and watersoluble proteins (simplified as salt-soluble protein) are usually localized in cytoplasm and called cystoplasmic protein. Sodium dodecyl sulphate (SDS) is a good solvent for membrane proteins (Ames and Nikaido, 1976; Hurkman and Tanaka, 1986), and SDS-soluble proteins are mainly considered as cell membrane proteins. In recent investigations, acquired thermotolerance of plants has been associated with the presence of HSPs in several plant species (Burke, 2001; Hong and Vierling, 2000; Malik et al., 1999; Queitsch et al., 2000). All major classes of HSPs are proposed to act as molecular chaperones, functioning by binding to substrate proteins that are in unstable, nonnative structural states (Gething, 1997). By virtue of this property, the different HSPs/chaperones are able to aid in a variety of cellular processes that involve assisted protein folding, including rescue of misfolded or aggregated proteins. This latter activity is presumed to explain their important role in heat stress, a condition that often leads to protein denaturation (Vierling, 1991).

Creeping bentgrass is a commonly used cool-season turfgrass grown in temperate regions of the world. Many cool-season turfgrasses are often subjected to heat stress during summer in warm climatic regions, exhibiting decline in turf quality and growth. A previous study showed that heat acclimation improved the ability of creeping bentgrass to survive subsequent exposure to potentially lethal temperatures (Larkindale and Huang, 2004). The induction of HSPs has been associated with enhanced heat tolerance in other perennial grass species (Al-Niemi and Stout, 2002). We hypothesized that increased thermotolerance of creeping bentgrass induced by heat acclimation could be related to expression of certain new proteins, and heat injury is associated with protein degradation. The objective of this study was to examine changes in protein content and expression during heat acclimation and sudden heat stress in creeping bentgrass. 


\section{Materials and Methods}

Plant materials and growth conditions. Sod plugs of 'Penncross' creeping bentgrass were collected from 3-year-old field plots at the Rutgers Univ. Horticulture Farm II, North Brunswick, N.J., in May 2002. They were transferred into polyvinyl chloride (PVC) tubes $(10 \mathrm{~cm}$ diameter and $60 \mathrm{~cm}$ long) filled with washed sand. Plants were maintained in a greenhouse for 1 month and then moved into a growth chamber at $20^{\circ} \mathrm{C}$ day/16 ${ }^{\circ} \mathrm{C}$ night temperature, $75 \%$ relative humidity, 14 -h photoperiod, and $400 \mu \mathrm{mol} \cdot \mathrm{m}^{-2} \cdot \mathrm{s}^{-1}$ photosynthetically active radiation (PAR). Plants were fertilized once per week with $40 \mathrm{~mL}$ Hoagland's solution (Hoagland and Arnon, 1950) and cut twice per week to keep the height at $\approx 5 \mathrm{~cm}$.

HEAT ACCLIMATION AND SUDDEN HEAT STRESS TREATMENTS. For heat acclimation treatment, eight tubes of plants were maintained at $20,25,30$, and $35^{\circ} \mathrm{C}$ (day/night temperature) for $7 \mathrm{~d}$ at each temperature before exposed to $40{ }^{\circ} \mathrm{C}$ for $28 \mathrm{~d}$. For sudden heat stress (nonacclimation), eight tubes of plants were exposed only to $20{ }^{\circ} \mathrm{C}$ for $7 \mathrm{~d}$ before exposure to $40{ }^{\circ} \mathrm{C}$ for $28 \mathrm{~d}$. Four growth chambers were used for each temperature at each 7-d period and during the $28 \mathrm{~d}$ of sudden heat stress. During sudden heat stress or heat acclimation, leaves were sampled once a week. Fresh samples were used to measure EL and frozen samples were kept at $-70{ }^{\circ} \mathrm{C}$ for protein analysis. During the temperature treatments, growth chambers were at $75 \%$ relative humidity, $14-\mathrm{h}$ photoperiod, and $400 \mu \mathrm{mol} \cdot \mathrm{m}^{-2} \cdot \mathrm{s}^{-1} P A R$. Plants were watered twice a day, fertilized once per week with $40 \mathrm{~mL}$ Hoagland's solution (Hoagland and Arnon, 1950), and cut twice per week to keep the height at $\approx 5 \mathrm{~cm}$.

Measurement of electrolyte leakage. Cell membrane stability was estimated by measuring electrolyte leakage (EL) following the method described by Liu and Huang (2000). Approximately $0.2 \mathrm{~g}$ of fresh leaves were randomly sampled from each of four pots in each treatment and cut into $1-\mathrm{cm}$ segments. Leaves were rinsed twice with de-ionized water and placed into test tubes containing $40 \mathrm{~mL}$ deionized water. Test tubes were then placed on a shaker for $24 \mathrm{~h}$ at $22^{\circ} \mathrm{C}$. Electrical conductivity (EC) of the solution containing fresh leaves $\left(\mathrm{EC}_{0}\right)$ was measured with a conductivity meter (YSI model 32; Yellow Springs Instrument Co., Yellow Springs, Ohio) at $22^{\circ} \mathrm{C}$. All leaves in each test tube were then killed at $100^{\circ} \mathrm{C}$ for $1 \mathrm{~h}$ in a water bath and left at room temperature for $2-4 \mathrm{~h}$ until cooled to $22^{\circ} \mathrm{C}$. EC of the solution containing killed leaves $\left(\mathrm{EC}_{100}\right)$ was measured with the conductivity meter described above. Relative conductivity, or relative $\mathrm{EL}(\%)$, was calculated as $\left(\mathrm{EC}_{0} / \mathrm{EC}_{100}\right) \times 100$.

ExTraCtion of PROTEINS AND QUANTIFICATION. Extraction of proteins from shoots was performed following the method described by Shimoni et al. (1997). Frozen leaves (0.5 $\mathrm{g}$ fresh weight) were ground in liquid $\mathrm{N}_{2}$ to fine powder. The powder was extracted in $3 \mathrm{~mL}$ of buffer containing $0.10 \mathrm{~mm}$ Tris- $\mathrm{HCl}$ ( $\mathrm{pH}$ 7.6) and $0.15 \mathrm{~m} \mathrm{NaCl}$ on ice bath (around $4{ }^{\circ} \mathrm{C}$ ) and then centrifuged twice at $16,000 g_{\mathrm{n}}$ at $4{ }^{\circ} \mathrm{C}$ for $30 \mathrm{~min}$. The resulting supernatant, containing the salt-soluble proteins, was kept for further analysis. The pellet was subsequently resuspended in 3 $\mathrm{mL}$ of the buffer containing $2 \%$ (w/v) SDS, $0.10 \mathrm{~mm}$ Tris-HCl (pH 7.6), and $0.15 \mathrm{~m} \mathrm{NaCl}$. Following extraction for $1 \mathrm{~h}$ at 4 ${ }^{\circ} \mathrm{C}$ with agitation, the suspension was centrifuged as described above and the supernatant, termed "SDS-soluble protein," was kept. Protein content of the supernatant was determined by the method of Bradford (1976). Briefly, $100 \mu$ L of protein extraction (diluted five times) was mixed with $3 \mathrm{~mL}$ of coomassie G-250 reagent $(0.01 \%$ coomassie brilliant blue $\mathrm{G}, 4.75 \%$ ethanol, and $8.5 \%$ phosphoric acid), and the absorbance was measured at 595 $\mathrm{nm}$ between 5 and $30 \mathrm{~min}$ after reaction using a spectrophotometer (Spectronic Genesys 2; Spectronic Instruments, Rochester, N.Y.). Bovine serum albumin was used as a standard.

ProteIn EXPRESSION. For protein expression sodium dodecyl sulphate-polyacrylamide gel electrophoresis (SDS-PAGE) was done according to the method of Laemmli (1970) with modifications. Salt-soluble protein extraction was dissolved in SDSPAGE sample buffer containing $75 \mathrm{~mm}$ Tris- $\mathrm{HCl}$ (pH 6.8), 50\% (w/v) sucrose, $10 \%(\mathrm{w} / \mathrm{v}) \mathrm{SDS}, 20 \%(\mathrm{v} / \mathrm{v}) \beta$-mercaptoethanol, and $1 \%$ bromophenol blue at the sample to buffer volume ratio of 4:1. Proteins were separated by discontinuous SDS-PAGE with an electrophoresis unit (PROTEIN II; Bio-Rad, La Jolla, Calif.) using a $6 \%$ stacking gel and $12 \%$ running gel. Gels were run at room temperature $\left(20-22{ }^{\circ} \mathrm{C}\right)$ and were stained overnight with coomassie brilliant blue R. Proteins with known molecular weights (MW) were used as markers to identify MW of proteins in the samples in each gel. As the log (MW) and the migration rate (distance the band migrated from the top of the separating gel divided by the distance migrated by the tracking dye of bromophenol) is linearly related when protein MW is between 12-200 $\mathrm{kDa}$ (Viney and Fenton, 1998), the distance and migration rate were used to calculate the MW of protein bands in the samples based on the linear regression of the markers in the same gel. By comparing protein profiles between control and high-temperature-treated samples, the proteins that were present only in treated samples, but were not present in the control were defined as heat shock proteins.

EXPERIMENTAL DESIGN AND STATISTICAL ANALYSIS. Treatments were arranged in a randomized complete-block design with four replicates (four pots for each treatment). Protein content was measured for three sub-samples taken from each extraction sample (replicate). The mean of the three sub-samples was used to represent a single replicate in the analysis of variance. Data were analyzed with analysis of variance using MicrosoftExcel 2000 (Microsoft Corp., Redmond, Wash.) (Levine et al., 2001) and mean separations were performed with the Fisher's protected least significance difference test at $P=0.05$ (Steel and Torrie, 1980).

\section{Results}

EFFECTS OF HEAT ACCLIMATION AND SUDDEN HEAT STRESS ON CELL MEMBRANE STABiLITY. Cell membrane stability decreased, as demonstrated by the increase in relative EL, with an increase in temperature from 20 to $35^{\circ} \mathrm{C}$ during heat acclimation. An increase of $32 \%$ in relative EL was observed at $25^{\circ} \mathrm{C}$ compared with that at control temperature $\left(20^{\circ} \mathrm{C}\right)$ as shown in Fig. $1 \mathrm{~A}$. During sudden heat stress $\left(40{ }^{\circ} \mathrm{C}\right)$, EL increased rapidly with the duration of treatment. The increase of $79 \%$ in relative EL was initially observed at $7 \mathrm{~d}$ of treatment compared with $0 \mathrm{~d}$ of treatment as shown in Fig. 1B. Plants exposed to increasing temperatures had significantly higher relative EL than those grown at $20{ }^{\circ} \mathrm{C}$ (Fig 1C, 0 d) but had $33 \%$ and $57 \%$ lower relative EL than unacclimated plants when both were exposed to $40{ }^{\circ} \mathrm{C}$ for 14 and $28 \mathrm{~d}$, respectively, as shown in Fig. 1C.

EFFECT OF HEAT ACCLIMATION AND SUDDEN HEAT STRESS ON PROTEIN CONTENT. Significant decreases in salt-soluble (Fig. 2) and SDS-soluble (Fig. 3) protein content were observed in plants exposed to gradually increasing temperatures from 20 to $35^{\circ} \mathrm{C}$ and sudden heat stress. A decrease of $12 \%$ in salt-soluble protein occurred when the temperature was increased to $25^{\circ} \mathrm{C}$ 


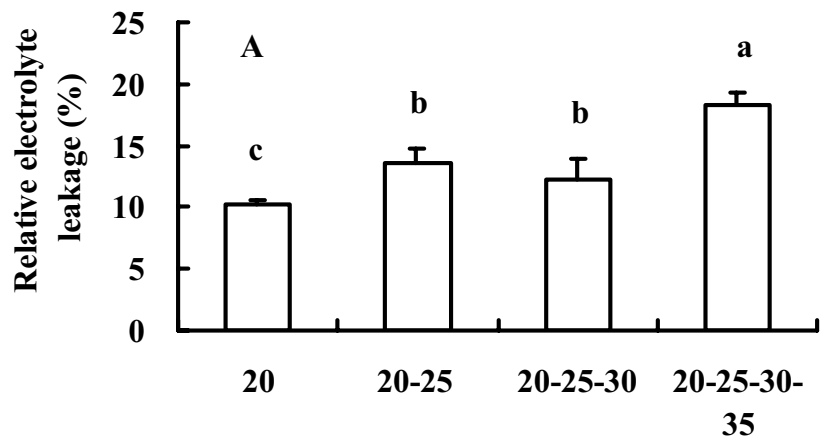

Heat acclimation $\left({ }^{\circ} \mathrm{C}\right)$

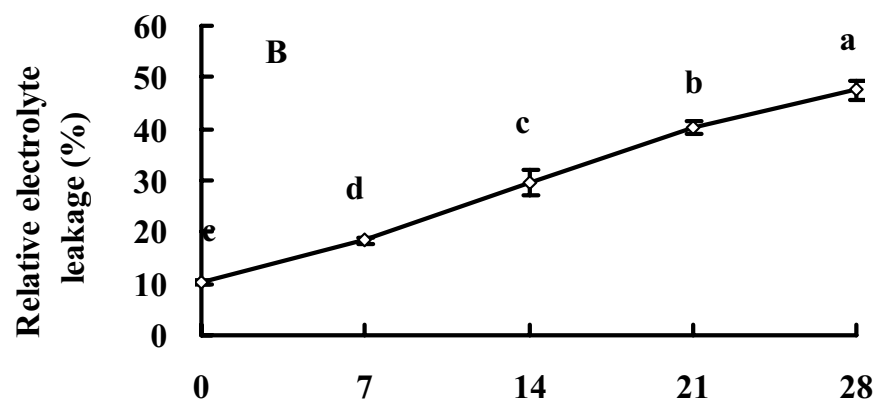

Duration of heat stress (d)

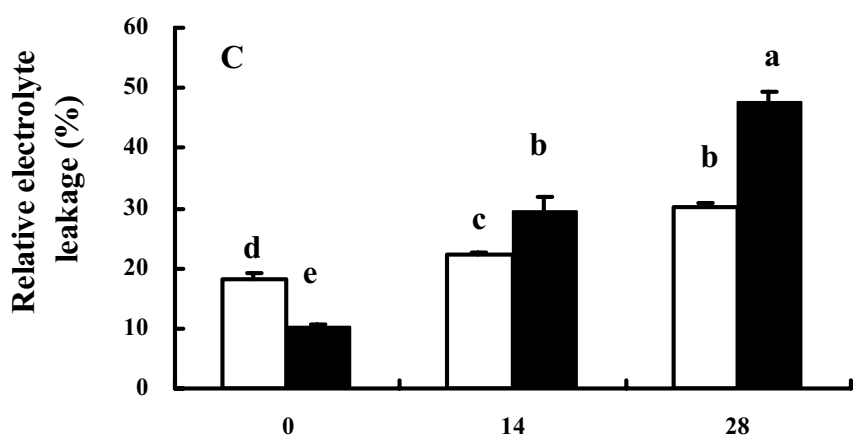

Duration of heat stress (d)

\section{$\square$ Acclimated U Unacclimated}

Fig. 1. Electrolyte leakage in leaves of creeping bentgrass during heat acclimation (A), under sudden heat stress $\left(40^{\circ} \mathrm{C}\right)(\mathbf{B})$, and at 0,14 , and $28 \mathrm{~d}$ of sudden heat stress for heat- acclimated and unacclimated plants $(\mathbf{C})$. Bars represent SE $(\mathrm{n}=$ 4) and different letters indicate a significant difference at $P=0.05$.

(Fig. 2A) and a decrease of $25 \%$ in SDS-soluble protein content decreased when temperature was increased to $30{ }^{\circ} \mathrm{C}$ (Fig. 3A) as compared with the control at $20^{\circ} \mathrm{C}$. Both salt-soluble and SDSsoluble protein content decreased with duration of sudden heat stress treatment as shown in Fig. 2B and Fig 3B, respectively. The decline in SDS-soluble protein content at $7 \mathrm{~d}$ of sudden heat stress was 54\% (Fig. 3B) and 8\% in salt-soluble protein content (Fig. 2B) as compared to that of control at $20^{\circ} \mathrm{C}$, which showed the changes of SDS-soluble protein content was more pronounced than that of salt-soluble protein content at $7 \mathrm{~d}$ of heat treatment.

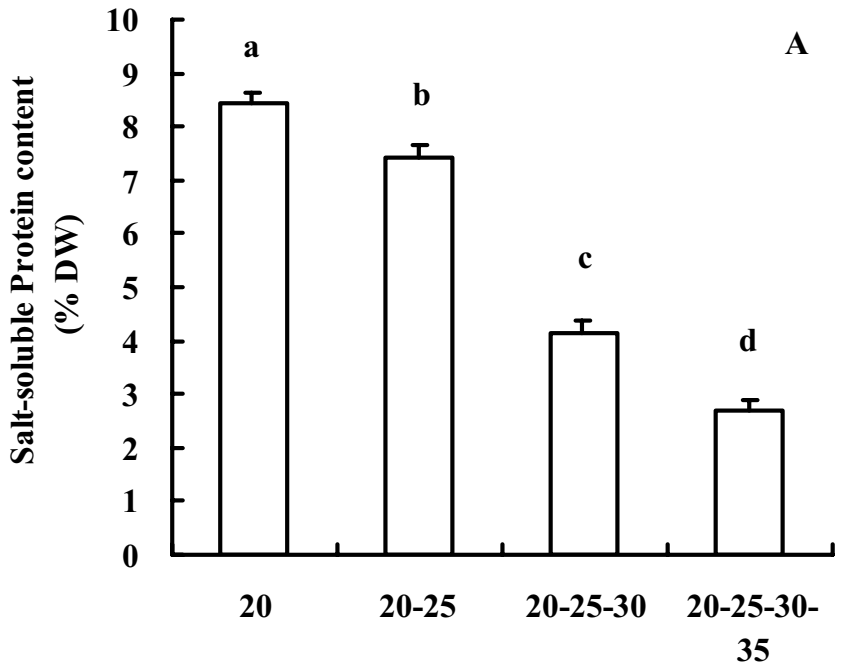

Heat acclimation $\left({ }^{\circ} \mathrm{C}\right)$

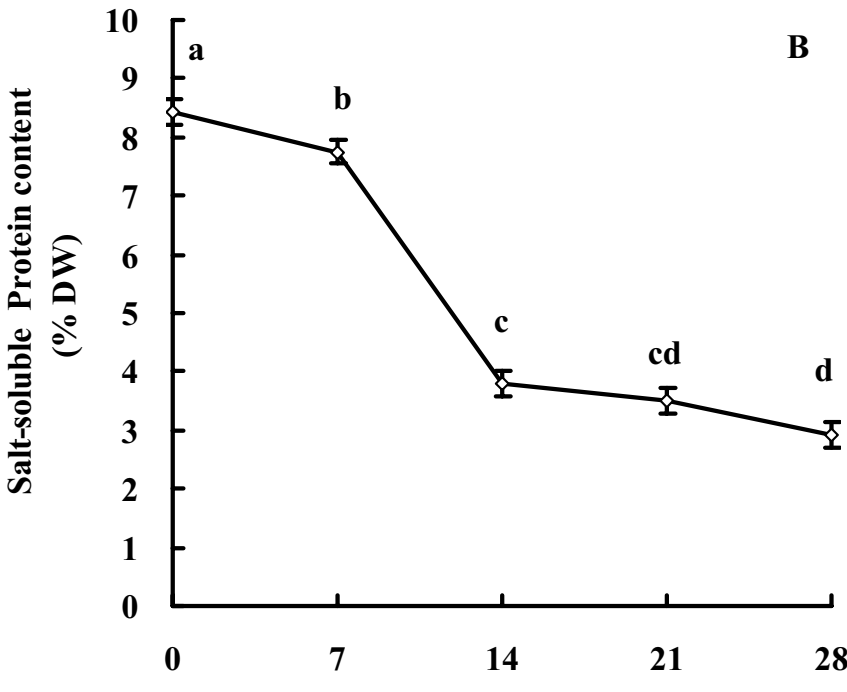

Duration of heat stress (d)

Fig. 2. Salt-soluble protein content [percent dry weight (DW)] in leaves of creeping bentgrass during heat acclimation $(\mathbf{A})$ and under sudden heat stress $\left(40{ }^{\circ} \mathrm{C}\right)(\mathbf{B})$. Bars represent SE $(\mathrm{n}=4)$ and different letters indicate a significant difference at $P=0.05$.

Plants exposed to increasing temperatures had significantly lower salt-soluble (Fig. 4A, 0 d) and SDS-soluble (Fig. 4B, 0 d) protein contents than plants maintained at $20^{\circ} \mathrm{C}$. However, no significant differences in salt-soluble (Fig. 4A) or SDS-soluble (Fig. 4B) protein content were observed between heat-acclimated and nonacclimated plants when both plants were exposed to heat stress $\left(40{ }^{\circ} \mathrm{C}\right)$ for 14 or $28 \mathrm{~d}$.

Protein EXPRESSION DURING HEAT ACCLIMATION AND SUDDEN HEAT STRESS. Proteins that were induced under heat stress but were absent under normal temperature $\left(20{ }^{\circ} \mathrm{C}\right.$ in this study) are considered HSPs. Some heat shock proteins (HSPs) were 

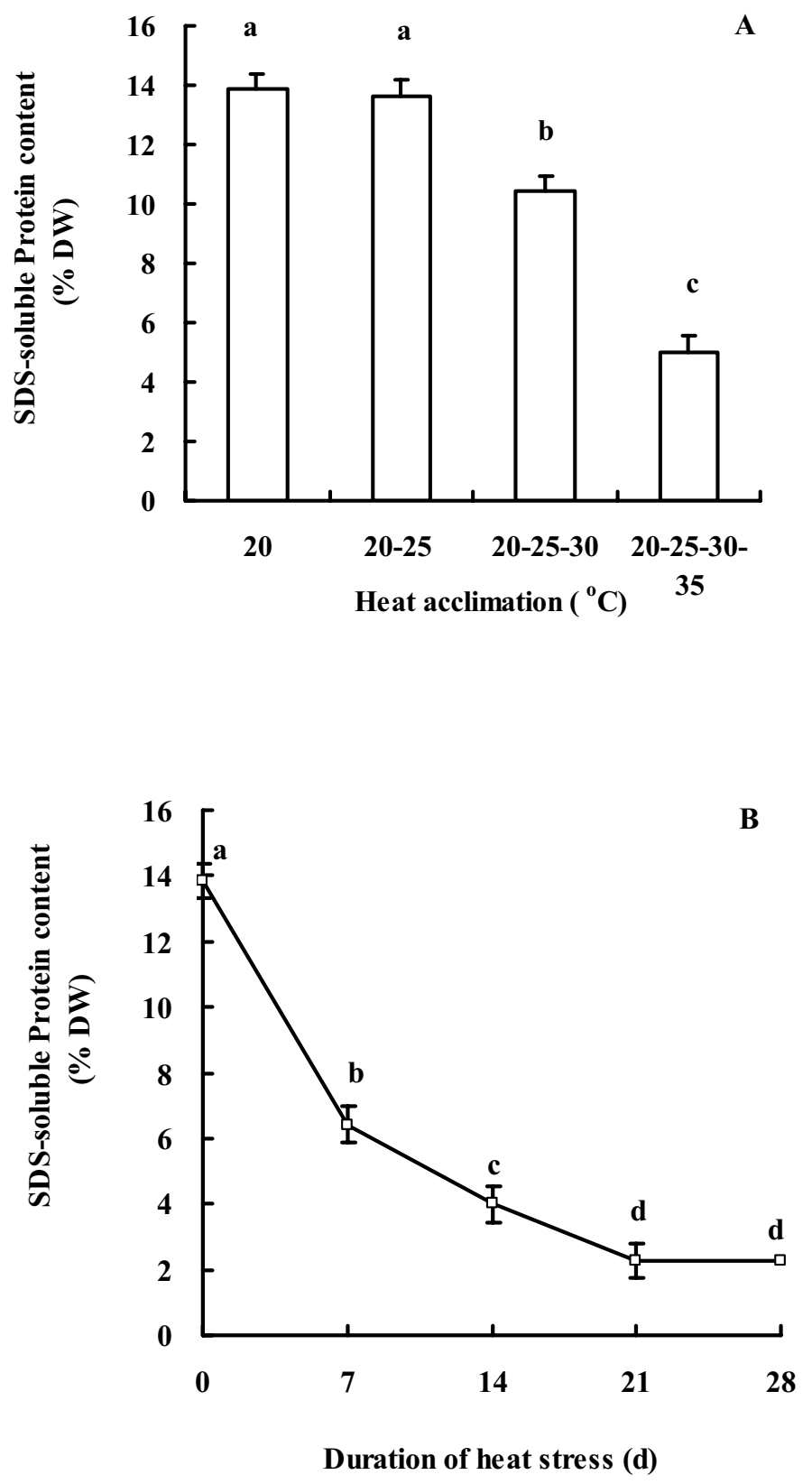

Fig. 3. Sodium dodecyl sulphate (SDS)-soluble protein content [percent dry weight (DW)] in leaves of creeping bentgrass during heat acclimation (A) and under sudden heat stress $\left(40^{\circ} \mathrm{C}\right)(\mathbf{B})$. Bars represent SE $(n=4)$ and different letters indicate a significant difference at $P=0.05$.

detected in the treatment of sudden exposure of plants to $40^{\circ} \mathrm{C}$, which occurred between 7 and $28 \mathrm{~d}$ after exposure to the stress (Fig. 5). Three HSPs with molecular weights of 23, 36, and 66 $\mathrm{kDa}$ were detected in heat-stressed plants (lanes 2 through 5 in Fig. 5), whereas these proteins were absent in the control plants exposed to $20^{\circ} \mathrm{C}$ (lanes 1 and 6 in Fig. 5). In addition to the three HSPs $(23,36$, and $66 \mathrm{kDa})$ as shown in plants exposed directly to $40{ }^{\circ} \mathrm{C}$, two additional HSPs, 54 and $57 \mathrm{kDa}$, were detected in heat-acclimated plants after the gradual increase in temperature from 20 to $35^{\circ} \mathrm{C}$ at $14 \mathrm{~d}$ of $40^{\circ} \mathrm{C}$ (lane 4 in Fig. 6). However, as heat stress was prolonged to $28 \mathrm{~d}$, the acclimation induced HSPs disappeared (lane 2 in Fig. 6). These two HSPs were not detected in plants directly exposed to $40{ }^{\circ} \mathrm{C}$ for $14 \mathrm{~d}$ and $28 \mathrm{~d}$ (lanes 3 and 5 in Fig. 6).

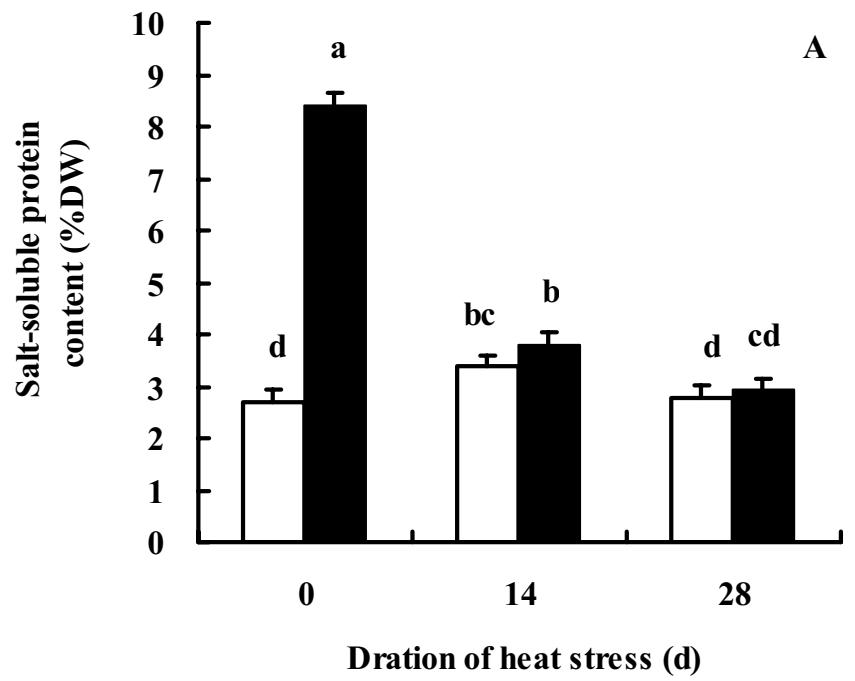

$\square$ Acclimated $\square$ Unacclimated

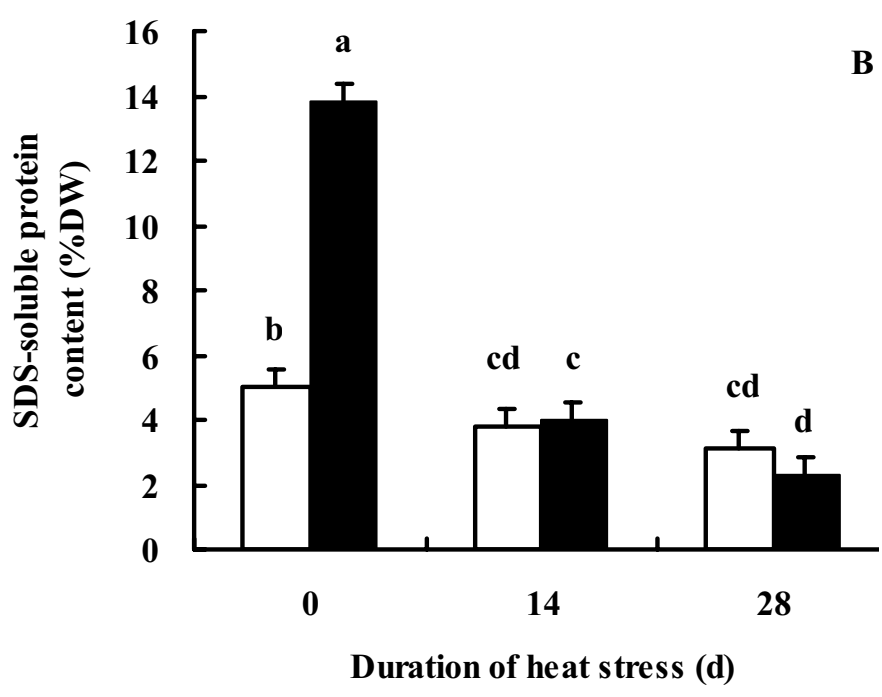

$\square$ Acclimated $\square$ Unacclimated

Fig. 4. Comparisons of salt-soluble (A) and sodium dodecyl sulphate (SDS)-soluble (B) protein content [percent dry weight (DW)] between heat acclimated and unacclimated creeping bentgrass under heat stress $\left(40^{\circ} \mathrm{C}\right)$. Bars represent SE (n $=4$ ) and different letters indicate a significant difference at $P=0.05$.

\section{Discussion}

Heat stress damages membrane systems and can lead to the leakage of electrolytes from plant cells (Levitt, 1980). The increase in relative EL indicates cell membrane damage had occurred. Cell membrane thermostability measured by the relative amount of EL from leaf segments exposed to a heat shock has been used to predict whole-plant thermotolerance for different turfgrass cultivars (Marcum, 1998). In this study, heat-acclimated plants had significantly lower EL than unacclimated plants when exposed to $40^{\circ} \mathrm{C}$ for 14 and $28 \mathrm{~d}$ (Fig. 1C). This result indicated that membrane destabilization was lower in acclimated leaves 


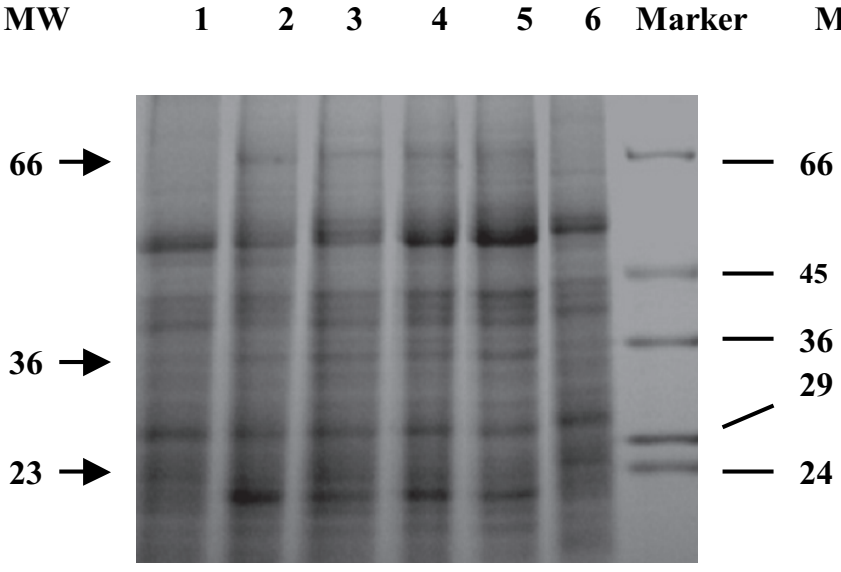

Fig. 5. Salt-soluble protein profile for creeping bentgrass exposed to sudden heat stress. Lane $1=20^{\circ} \mathrm{C}$ for $7 \mathrm{~d}$, lane $2=40^{\circ} \mathrm{C}$ for $7 \mathrm{~d}$, lane $3=40^{\circ} \mathrm{C}$ for $14 \mathrm{~d}$, lane $4=40^{\circ} \mathrm{C}$ for $21 \mathrm{~d}$, lane $5=40^{\circ} \mathrm{C}$ for $28 \mathrm{~d}$, lane $6=20^{\circ} \mathrm{C}$ for $7 \mathrm{~d}$. Equal amounts of protein $(18 \mu \mathrm{g})$ were loaded in each lane. Arrows indicate newly induced proteins under sudden heat stress. $\mathrm{MW}=$ molecular weight, Marker = standard protein with known MW.

than those in nonacclimated plants being exposed to heat stress, which may contribute to the enhanced creeping bentgrass tolerance to subsequent exposure as previously reported by Larkindale and Huang (2004).

Proteins are localized mainly in cellular membranes as insoluble form and cytoplasms in the soluble form. Membrane proteins have good solubility in SDS (Ames and Nikaido, 1976; Hurkman and Tanaka, 1986), and thus in the present study, SDS-soluble proteins are considered as membrane proteins and salt-soluble proteins are mainly cystoplasmic proteins. Synthesis of normal proteins in either soluble or membrane form usually decreases under heat stress conditions (Key et al., 1981). Both heat acclimation through gradual exposure to temperatures from 20 to $35^{\circ} \mathrm{C}$ before exposure to $40{ }^{\circ} \mathrm{C}$ and sudden exposure of plants from 20 to $40{ }^{\circ} \mathrm{C}$ caused reduction in the content of both salt-soluble (Fig. 2) and SDS-soluble protein (Fig. 3) groups. A significant net decline in salt-soluble cytoplasmic protein content occurred at $25^{\circ} \mathrm{C}$ (Fig. 2A), while a significant net decline in SDS-soluble membrane proteins was not detected until temperature was increased to $30^{\circ} \mathrm{C}$ (Fig. 3A), suggesting that soluble cystoplasmic protein was more susceptible to a gradual increase in temperatures than membrane proteins. A decrease in soluble protein content with increasing temperatures has also been detected in other species (Zhou et al., 1995). In our study, the net decline in soluble and insoluble membrane protein content corresponded with the increase in EL under both heat acclimation and sudden heat stress conditions. It is reasonable to infer that the net decline in protein content could be associated with heat injury in shoots, as manifested by the increased EL.

The decrease in normal protein synthesis is often accompanied by the synthesis and accumulation of HSPs. High-molecular-mass HSPs (HSP70, HSP90, HSP100) are characterized by a high level of sequence similarity within the plant kingdom (Maestri et al., 2002). The low-molecular-mass HSPs are the most abundant proteins induced by heat stress in higher plants (Vierling, 1991). A study of the heat shock response in creeping bentgrass variants indicated that both selected heat-tolerant lines (SB) and nonselected (non-heat tolerant) lines (NSB) from a parent cultivar, 'Penncross', synthesized HSPs of 97, 83, 70, 40, 27, and $18 \mathrm{kDa}$ in $1-\mathrm{cm}$ leaf segments incubated at $40^{\circ} \mathrm{C}$ for $1.5 \mathrm{~h}$

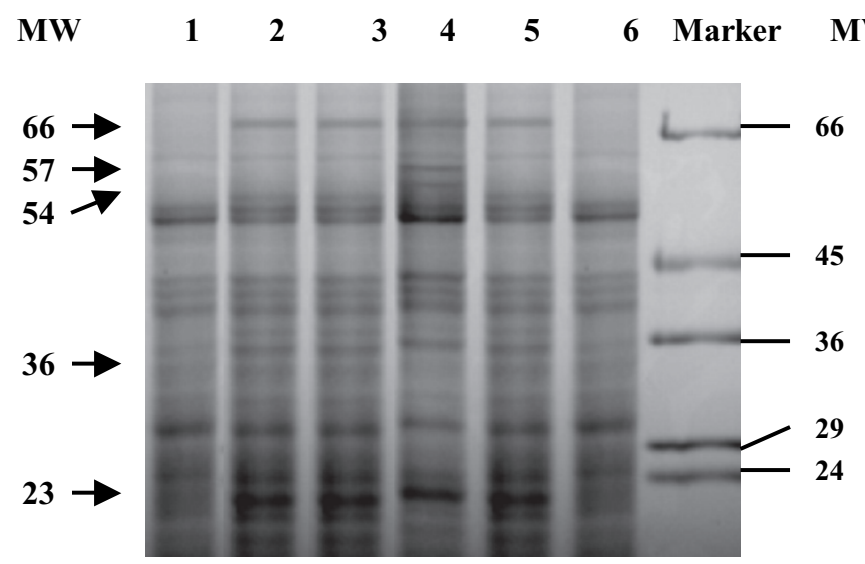

Fig. 6. Comparison of salt-soluble protein profiles for creeping bentgrass during heat acclimation and sudden heat stress. Lane $1=20^{\circ} \mathrm{C}$ for $7 \mathrm{~d}$; lane $2=40^{\circ} \mathrm{C}$ for $28 \mathrm{~d}$ after exposure for $7 \mathrm{~d}$ at each temperature $\left(20,25,30,35^{\circ} \mathrm{C}\right)$; lane $3=$ direct exposure to $40^{\circ} \mathrm{C}$ for $28 \mathrm{~d}$; lane $4=40^{\circ} \mathrm{C}$ for $14 \mathrm{~d}$ after exposure for 7 $\mathrm{d}$ at each temperature $\left(20,25,30,35^{\circ} \mathrm{C}\right)$; lane $5=$ direct exposure to $40^{\circ} \mathrm{C}$ for $14 \mathrm{~d}$; lane $6=20^{\circ} \mathrm{C}$ for $7 \mathrm{~d}$. Equal amounts of protein $(18 \mu \mathrm{g})$ were loaded in each lane. Arrows indicate newly induced proteins. $\mathrm{MW}=$ molecular weight, Marker $=$ standard protein with known MW.

(Park et al., 1996). In our study, we used the Penncross cultivar that is developed from the open pollination of three genotypes to investigate heat induction of HSPs in a genetically balanced population. HSPs of 66,36 , and $23 \mathrm{kDa}$ were detected in leaves of 'Penncross' creeping bentgrass when the whole plant was exposed to $40{ }^{\circ} \mathrm{C}$ for 7 to $28 \mathrm{~d}$. HSP66 is a member of the HSP60 family, which has been found to facilitate proper folding of other proteins (Vierling, 1991). HSP23 has also been found to accumulate abundantly at $40{ }^{\circ} \mathrm{C}$ in tomato (Lycopersicon esculentum Mill.) leaves, which served as molecular chaperons in an in vitro test (Liu and Shono, 1999). HSP36 has also been detected in tomato (Rose et al., 2003), but the function of this protein is unknown and warrants further study.

HSP induction has been correlated with acquired thermotolerance (Kimpel and Key, 1985; Krishnan et al., 1989; Lin et al., 1984; Lindquist, 1986). Park et al. (1996) reported that heat tolerant line "SB" of creeping bent grass synthesized two additional HSP25 polypeptides that did not accumulate in non-heat tolerant line "NSB." The production of these additional HSP25 isoforms was genetically correlated with improved thermotolerance. Creeping bentgrass plants with the additional HSP25 polypeptides recovered from heat stress faster and were able to resume typical levels of protein synthesis $\approx 2 \mathrm{~h}$ earlier than those without the new protein expression (Park et al., 1997). Park et al. (1996) also proved that these two additional HSP25 could only be extracted by phenol extraction procedure, which was developed for the efficient isolation of membrane-associated proteins (Hurkman and Tanaka, 1986). In the present study, HSP23, a member of small heat shock protein family, was detected in both heat acclimated plants and unacclimated plants, which indicated that HSP23 may be the result of a general response of plants to increasing temperatures, but not specifically involved in heat acclimation.

Heat acclimation induced two unique HSPs, 57 and $54 \mathrm{kDa}$ (Fig. 5). These two proteins were not expressed in unacclimated creeping bentgrass plants. The functions of these HSPs are unknown in higher plants, except for limited studies in other organisms (Gerner et al., 2000). The 57-kDa cytoplasmic protein binds to the promoters of heat-shock genes and activates transcription during heat shock in human cells (Soncin et al., 
1997). HSP54 has been found to be correlated with the reduction of copper toxicity in sponge (Crambe crambe L.) (Agell et al., 2001). It is possible that the two additional polypeptides, HSP57 and HSP54, may contribute to acquired thermotolerance through acclimation since only acclimated plants that exhibited better heat tolerance had the expression of those proteins. Investigation of the functions of these unique HSPs in creeping bentgrass might provide insight into mechanisms of acquired thermotolerance in cool-season grasses.

In summary, heat acclimation enhanced creeping bentgrass tolerance to subsequent heat stress, as manifested by increased membrane thermostability. The exposure of plants to a gradual increase in temperature and sudden heat stress induced the expression of some HSPs, but different HSPs were synthesized in heat-acclimated plants compared to heat-stressed plants, suggesting that the unique HSPs expressed during heat acclimation may contribute to the enhanced thermotolerance due to heat acclimation. Gradual increases in temperature and direct exposure to heat stress also caused the degradation of normal proteins, which may be associated with heat injury in leaves.

\section{Literature Cited}

Agell, G., M.J. Uriz, E. Cebrian, and R. Marti. 2001. Does stress protein induction by copper modify natural toxicity in sponges? Environ. Toxicology Chem. 20:2588-2593.

Al-Niemi, T.S. and R.G. Stout. 2002. Heat shock protein expression in a perennial grass commonly associated with active geothermal areas in western North America. J. Thermal Biol. 27:547-553.

Ames G.F-L. and K. Nikaido. 1976. Two-dimensional gel electrophoresis of membrane proteins. Biochemistry15:616-623.

Bradford, M.M. 1976. A rapid and sensitive method for the quantification of microgram quantities protein using the principle of protein-dye binding. Anal. Biochem. 72:248-254.

Burke, J.J. 2001. Identification of genetic diversity and mutations in higher plant acquired thermotolerance. Physiol. Plant. 112:167-170.

Gerner, C., F. Ulrike, G. Josef, B. Editha, G. Dieter, B. Wilfried, and S.H. Rolf. 2000. The Fas-induced apoptosis analyzed by high throughput proteome analysis. J. Biol. Chem. 275:39018-39026.

Gething M.J. 1997. Guidebook to molecular chaperones and protein folding catalysts. Oxford Univ. Press, New York.

Hoagland, C.R. and D.I. Arnon. 1950. The solution-culture method for growing plants without soil. Calif. Agr. Expt. Circ. 347.

Hong, S.W. and E. Vierling. 2000. Mutants of Arabidopsis thaliana defective in the acquisition of tolerance to high temperature stress. Proc. Natl. Acad. Sci. USA 97:4392-4397.

Hong, S.W., U. Lee, and E. Vierling. 2003. Arabidopsis hot mutants define multiple functions required for acclimation to high temperatures. Plant Physiol. 132:757-767.

Howarth, C.J., C.J. Pollock, and J.M. Peacock. 1997. Development of laboratory-based methods for assessing seedling thermotilerance in pearl millet. New Phytol. 137:129-139.

Hurkman, W.J. and C.K. Tanaka. 1986. Solubilization of plant membrane proteins for analysis by two-dimensional gel electrophoresis. Plant Physiol. 81:802-806.

Key, J.L., C.Y. Lin, and Y.M. Chen. 1981. Heat shock proteins in higher plants. Proc. Natl. Acad. Sci. USA 78:3526-3530.

Kimpel, J.A. and J.L. Key. 1985. Heat shock in plants. Trends Biochem. Sci. 10:353-357.

Krishnan, M., H.T. Nguyen, and J.J. Burke. 1989. Heat shock protein synthesis and thermal tolerance in wheat. Plant Physiol. 90:140-145.

Larkindale, J. and B. Huang. 2004. Changes of lipid composition and saturation level in leave and roots for heat-stressed and heat-acclimated creeping bentgrass (Agrostis stolonifera). Environ. Expt. Bot. $51: 1,57-67$.
Laemmli, U.K. 1970. Cleavage of structure proteins during the assembly of the head of bacteriophage T4. Nature 227:680-685.

Levine, D.M., P.P. Ramsey, and R.K. Smidt. 2001. Applied statistics for engineers and scientists: Using Microsoft Excel and MINITAB. Prentice-Hall, Upper Saddle River, N.J.

Levitt, J. 1980. Response of plants to environmental stresses. vol. 1. Academic, New York.

Lin, C.Y., J.K. Roberts, and J.L. Key. 1984. Acquisition of thermotolerance in soybean seedlings. Plant Physiol. 74:152-160.

Lindquist, S. 1986. The heat shock response. Ann. Rev. Biochem. 45:39-72.

Liu, J. and M. Shono. 1999. Characterization of mitochondria-located small heat shock protein from tomato (Lucopersicon esculentum). Plant Cell Physiol. 40:1297-1304.

Liu, X. and B. Huang. 2000. Heat stress injury in relation to membrane lipid peroxidation in creeping bentgrass. Crop Sci. 40:503-510.

Loponen J., M. Mikola, K. Katina, T. Sontag-Strohm, and H. Salovaara. 2004. Degradation of HMW glutenins during wheat sourdough fermentations. Cereal Chem. 81(1):87-93.

Maestri, E., N. Klueva, C. Perrotta, M. Gulli, H.T. Nguyen, and N. Marmiroli. 2002. Molecular genetics of heat tolerance and heat shock proteins in cereals. Plant Mol. Biol. 48:667-681.

Malik, M.K., J.P. Slovin, C.H. Huang, and J.L. Zimmerman. 1999. Modified expression of a carrot small heat shock protein gene, HSP17.7, results in increased or decreased thermotolerance. Plant J. 20:89-99.

Marcum, K.B. 1998. Cell membrane thermostability and whole-plant heat tolerance of kentucky bluegrass. Crop Sci. 38:1214-1218.

Nguyen, H.T., C.P. Joshi, N. Klueva, J. Weng, K.L. Hendershot, and A. Blum. 1994. The heat-shock response and expression of heat-shock proteins in wheat under diurnal heat stress and field conditions. Austral. J. Plant Physiol. 21:857-867.

Park, S.Y., K.C. Chang, R. Shivaji, and D.S. Luthe. 1997. Recovery from heat shock in heat-tolerant and nontolerant variants of creeping bentgrass. Plant Physiol. 115:229-240.

Park, S.Y., R. Shivaji, J.V. Krans, and D.S. Luthe. 1996. Heat-shock response in heat-tolerant and nontolerant variants of Agrostis palustris Huds. Plant Physiol. 111:515-524.

Queitsch, C., S.W. Hong, E. Vierling, and S. Lindquist. 2000. Heat shock protein 101 plays a crucial role in thermotolerance in arabidopsis. Plant Cell 12:479-492.

Radin, J.W., Z. Lu, R.G. Percy, and E. Zeiger. 1994. Genetic variability for stomata conductance in pima cotton and its relation to improvements of heat adaptation. Proc. Natl. Acad. Sci. USA 91:7217-7221.

Raison, J.K., J.A. Berry, P.A. Armond, and C.S. Pike. 1980. Membrane properties in relation to the adaptation of plants to temperature stress, $\mathrm{p}$. 261-273. In: N.C. Turner and P.J. Kramer (eds.). Adaptation of plants to water and high temperature stress. Wiley, New York.

Rose, A., F. Gindullis, and I. Meier. 2003. A novel alpha-helical protein, specific to and highly conserved in plants, is associated with the nuclear matrix fraction. J. Expt. Bot. 54:1-9.

Shimoni Y., A.E. Blechel, O.D. Anderson, and G. Galili. 1997. Arecombinant protein of two high molecular weight glutenins alters gluten polymer formation in transgenic wheat. J. Biol. Chem. 272:15488-15495.

Soncin, F., R. Prevelige, and S.K. Calderwood. 1997. Expression and purification of human heat-shock transcription factor 1. Protein Expression Purification 9:27-32.

Steel, R.G.D. and J.H. Torrie. 1980. Principles and procedures of statistics. 2nd ed. McGraw-Hill, New York.

Vierling, E. 1991. The role of heat shock proteins in plants. Annu. Rev. Plant Physiol. Plant Mol. Biol. 42:579-620.

Viney C. and R.A. Fenton. 1998. Physics and gel electrophoresis: Using terminal velocity to characterize molecular weight. Eur. J. Physics 19:575-580.

Zhou, R.G., Z.H. Fan, X.Z. Li, Z.W. Wang, and W. Han. 1995. The effect of heat acclimation on membrane thermostability and relative enzyme activity. Acta Agron. Sinica 21:568-572. 